\title{
OPERATORS EXPOSURE TO WHOLE-BODY VIBRATION WHILE PERFORMING FOREST SOIL PREPARATION BY BULLDOZER AND HYDRAULIC EXCAVATORS
}

\author{
${ }^{1}$ Lucas Carvalho dos Santos, ${ }^{2}$ Eduardo da Silva Lopes, ${ }^{3 *}$ Alysson Braun Martins, ${ }^{4}$ Carla Krulikowski Rodrigues \\ Universidade Estadual do Centro Oeste - Irati, Paraná, Brasil - ${ }^{1}$ lucascsantos1998@ gmail.com; ${ }^{2}$ eslopes@ unicentro.br; \\ *alyssonbmartins@gmail.com \\ Universidade Federal do Paraná - Curitiba - Paraná - Brasil - ${ }^{4}$ carlakr@ gmail.com \\ Received for publication: 28/06/2020 - Accepted for publication: 26/03/2021
}

\begin{abstract}
Resumo
Vibração de corpo inteiro em operadores no preparo de solo florestal com trator de esteira e escavadeira hidráulica. Os níveis de vibração de corpo inteiro (VCI) nas operações mecanizadas de preparo do solo são preocupantes devido ao tempo de exposição dos operadores em seus postos de trabalho, topografia do terreno adversa e tipos de rodados das máquinas empregados. Assim, objetivou-se avaliar a exposição à VCI no trator de esteiras e na escavadeira hidráulica durante o preparo do solo para implantação florestal, de forma a identificar possíveis problemas ergonômicos e propor melhoria das condições de trabalho. $\mathrm{O}$ estudo foi conduzido no Paraná, Brasil, em áreas de implantação do híbrido Eucalyptus urophylla $\times$ Eucalyptus grandis, sendo registradas com uso de um medidor de vibração e acelerômetro triaxial acoplado ao assento das máquinas, aceleração resultante à exposição normalizada (aren) e a dose de vibração resultante (VDVR) para um período de 8 horas de trabalho, seguindo a Norma de Higiene Ocupacional 09. Os resultados mostraram valores de aren e VDVR de $1,0 \mathrm{~m} \mathrm{~s}^{-2} \mathrm{e} 18,3 \mathrm{~m} \mathrm{~s}^{-1,75}$ no trator de esteiras, enquanto na escavadeira hidráulica foi $0,7 \mathrm{~m} \mathrm{~s}^{-2}$ e $13,5 \mathrm{~m} \mathrm{~s}^{-1,75}$, respectivamente, com diferença estatística significativa entre as máquinas pelo teste Wilcoxon para amostras independentes $(\alpha<0,05)$. Os níveis de VCI estavam acima do nível de ação e abaixo do limite de exposição em ambas as máquinas, sendo que o trator de esteiras apresentou valores acima do nível de incerteza. Portanto, a substituição por máquinas projetadas especificamente para a realização do preparo de solo e melhorias organizacionais do trabalho são medidas indicadas para a redução dos problemas ergonômicos. Palavras-chave: Ergonomia; mecanização florestal; silvicultura; subsolagem; vibração mecânica.
\end{abstract}

\begin{abstract}
The levels of exposure whole-body vibration (WBV) while performing mechanized soil preparation operations are concerning due to the exposure time of operators at their work stations, adverse terrain topography, and types of wheels on the machines used. Thus, this study aimed to evaluate the exposure to WBV in bulldozers and hydraulic excavators in performing soil preparation for forest plantation in order to identify possible ergonomic problems and propose improvements in working conditions. The study was carried out in Paraná State, Brazil, in a Eucalyptus urophylla $\times$ Eucalyptus grandis stand hybrid, being registered with use of a vibration meter and triaxial accelerometer coupled to the seat of the machines, the resulting acceleration to normalized exposure (aren) and the resulting vibration dose (VDVR) for a period of 8 working hours, following the Occupational Hygiene Standard 09. The results showed aren and VDVR values of $1.0 \mathrm{~m} \mathrm{~s}^{-2}$ and $18.3 \mathrm{~m} \mathrm{~s}^{-}$ 1.75 in the bulldozer, while in the hydraulic excavator it was $0.7 \mathrm{~m} \mathrm{~s}^{-2}$ and $13.5 \mathrm{~m} \mathrm{~s}^{-1.75}$, respectively, with a statistically significant difference between the machines by the Wilcoxon test for independent samples $(\alpha \leq$ 0.05). The WBV levels were above the action level and below the exposure limit in both machines, with the bulldozer showing values above the uncertainty level. Therefore, substituting machines specifically designed for soil preparation and improvements in work organization are measures indicated to reduce ergonomic problems.

Keywords: Ergonomics; forest mechanization; silviculture; subsoiling; mechanical vibration.
\end{abstract}

\section{INTRODUCTION}

The planted forest sector in Brazil consists of 7.8 million hectares and presented a growth of $38 \%$ in area between the years 2005 and 2018, standing out worldwide due to the favorable soil and climate conditions for obtaining high productivity for Eucalyptus and Pinus stands. However, this growth is also due to the investment in high-tech machinery and equipment used in the production process, as a total of $\mathrm{R} \$ 3.9$ billion was invested in forests in Brazil only in 2018, with 6\% allocated for the acquisition of machinery and forestry equipment (IBÁ, 2019).

Such machines usually have embedded technology that has significantly leveraged productivity rates, being able to reduce operating costs, and their modern designs can provide better comfort and safety conditions for operators (LABELLE et al., 2018; MALINEN et al., 2018). On the other hand, the mechanization of forestry operations in terms of technology still has much to be developed when compared to wood harvesting machines (GUERRA et al., 2020). 
It is common to use the minimum cultivation technique in soil preparation for forest implementation to mitigate soil compaction, since it is a problem commonly found in establishing new forest plantations, mainly being caused by the intense traffic of machines in the wood harvest (RODRIGUES et al., 2018). In addition, soil preparation serves to assist the insertion of soil seedlings during planting. This preparation can be done by subsoiling, with soil revolving only in the planting line and the use of tractors and implements adapted to the adverse conditions of forest areas (GONÇALVES et al., 2016).

Subsoiling stands out among the soil preparation activities due to its beneficial effects for plant development, facilitating the uptake of water and nutrients, stimulating their growth and productivity gains. In addition, subsoiling tends to provide operational and economic advantages, enabling a 23\% reduction in forest reform costs and greater efficiency of labor use in sloping areas (56\%) and flat areas (up to 86\%) (RAPER, 2007).

Adapted agricultural tractors or specific wood harvesting machines are usually used in soil preparation activities for forest implementation, such as the skidder, also adapted with implements. However, machinery with specific characteristics for certain functions (purpose-built) are not yet a reality in medium and large companies in Brazil, being one of the main factors that can influence the comfort and health of operators in terms of machine ergonomics.

In order to leverage soil preparation productivity rates in forest planting, Brazilian companies have been using tracked tractors with high traction capacity adapted with subsoiling implements and "V"-shaped front blades which lower tree stumps. Thus, productivity increases due to the fact that two activities can be carried out with just one machine. Therefore, the replacement of traditional agricultural tractors with machines of greater power and traction has been frequent. However, these machines are limited on steep slopes, requiring the use of other machines on hilly terrain, such as excavators with a characteristic implement for soil reworking only in the planting rows (GONÇALVES et al., 2016).

Despite the gradual evolution in terms of productivity in soil preparation, problems from the ergonomic point of view may arise in these workstations, either by the operational characteristic of the activity with the presence of obstacles in the soil which can cause many jolts, or by the design characteristics of the machines. Occupational exposure by operators to high levels of whole-body vibration (WBV during the workday stands out among the ergonomic factors, which together with the repetitive movements performed and the improper postures adopted can not only compromise comfort, but consequently health and safety (GERASIMOV; SOKOLOV, 2014; SCHETTINO et al., 2019).

WBV can be understood as the transmission of mechanical energy existing in machines to the sitting or standing body of operators, and can cause loss of sensation in the limbs, discomfort, skeletal and gastrointestinal disorders, early degeneration of the spine, and herniated discs (BURSTRÖM et al., 2015), and some symptoms of disorders occur in the form of fatigue, insomnia, headache, and tremors (SALIBA, 2019).

Several studies, such as those by Häggström et al. (2016), Ji et al. (2017) and Adam and Jalil (2017), have been developed to demonstrate the ergonomic risks that machines in forestry operations can provide to the health of operators, which often present WBV that exceed the limits established by the International Organization for Standardization - ISO 2631 (1978). However, studies that emphasize an evaluation of occupational exposure to vibration in machines used in forest soil preparation are still scarce, as well as information about the occupational risks that this type of activity can cause to operators.

In view of the above, the aim of this study was to evaluate occupational exposure to whole-body vibration at the work station of a bulldozer and a hydraulic excavator in a soil preparation operation for forest plantation in order to identify possible ergonomic problems and propose solutions to improve the comfort, health, and safety conditions of the operators.

\section{MATERIAL AND METHODS}

The study was carried out in a forestry company located in the municipality of Telemaco Borba, Paraná State, Brazil, in the forest planting activities of the Eucalyptus urophylla S.T. Blake $\times$ Eucalyptus grandis Hill ex Maiden hybrid. The climate of the region was classified as subtropical (Cfa) according to the Köppen classification, with mean annual temperatures between 17.1 to $18.0^{\circ} \mathrm{C}$ and mean annual rainfall between 1,400 to 1,600 mm (ALVARES et al., 2013). The soil was classified as Red Latosol (Oxisol) of clayey texture (SANTOS et al., 2018).

Two types of machines were evaluated for subsoiling operation, defined according to the slope of the land (Table 1), namely: (1) in flat areas $\left(0\right.$ to $\left.20^{\circ}\right)$, a bulldozer with front implement ( $V$-Shear) for lowering the remaining stumps and rear implement for subsoiling (Savannah); and (2) in areas with slopes $\left(20\right.$ to $\left.30^{\circ}\right)$, a hydraulic excavator with three subsoiling rods in the implement. The characteristics of the study area are described in Table 2. 
Table 1. Characterization of the machines used: bulldozer (left) and hydraulic excavator (right).

Tabela 1. Caracterização das máquinas usadas: trator de esteira (esquerda); e escavadeira hidráulica (direita).

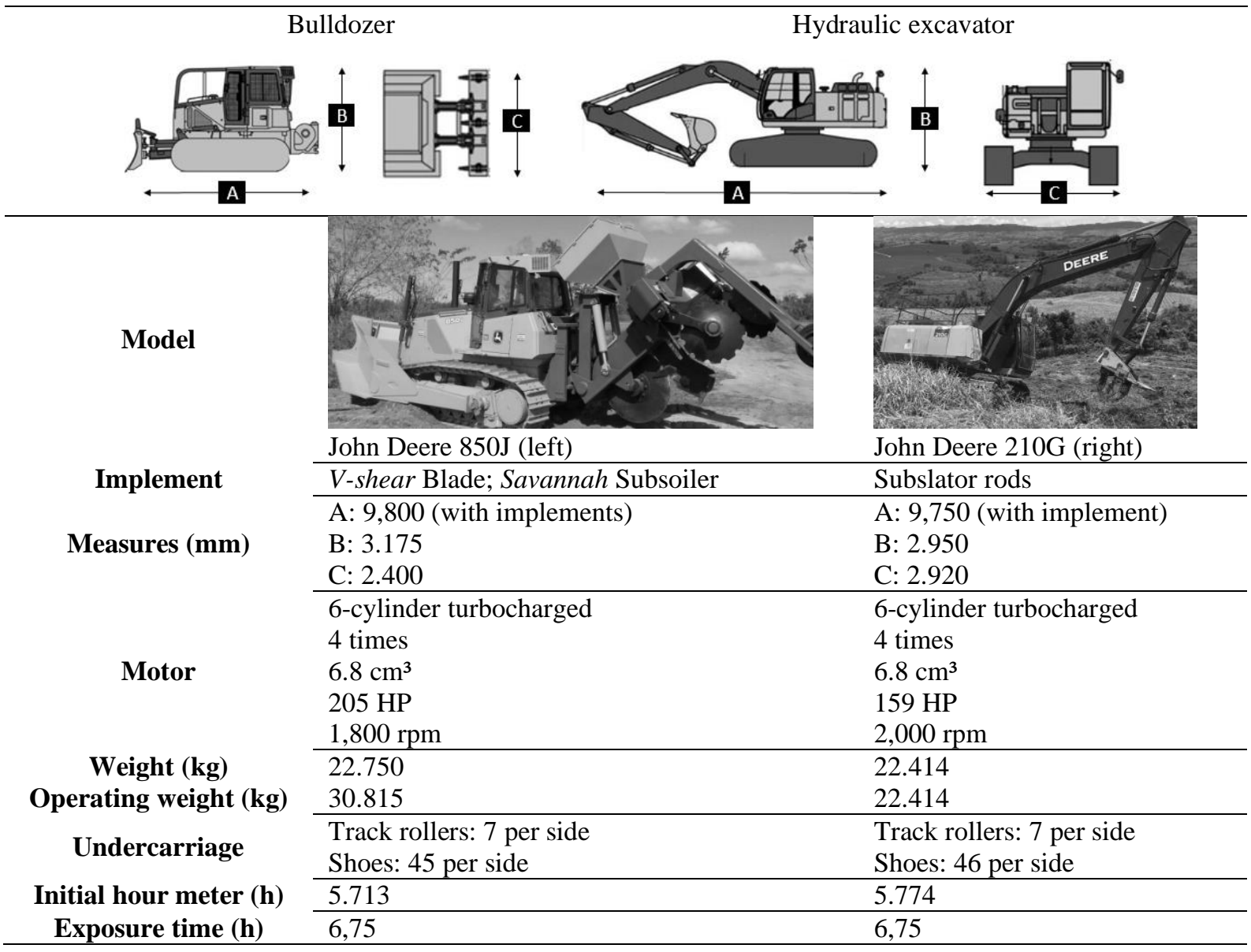

Legend: $\mathrm{cm}$ is centimeter; HP is horse power; rpm is revolutions per minute; $\mathrm{h}$ is hours; $\mathrm{cm}^{3}$ is cubic centimeters; $\mathrm{mm}$ is millimeters; and $\mathrm{kg}$ is kilogram.

Table 2. Study area.

Tabela 2. Área de estudo.
Previous stand
E. urophylla $\times$ E. grandis hybrid
Cutting age (Years-old)
7
Previously used harvesting system
Cut-to-length
New planting spacing $(\mathrm{m} \times \mathrm{m})$
$3.30 \times 1.80$
Subsoiling depth $(\mathrm{cm})$
50

Legend: $\mathrm{m}$ is meters; and $\mathrm{cm}$ is centimeters.

The data collection was performed during the day shift, with data collected for 25 consecutive minutes during ten days of operation. The samples were randomly collected on 5 days for each machine with different operators (Table 3).

Table 3. Characterization of the operators evaluated.

Tabela 3. Caracterização dos operadores avaliados.

\begin{tabular}{cccccc}
\hline Parameter & Age (years) & Height $(\mathbf{c m})$ & Mass $(\mathbf{k g})$ & BMI $\left(\mathbf{k g ~ m}^{-2}\right)$ & $\begin{array}{c}\text { Experience } \\
\text { (years) }\end{array}$ \\
\hline Average & 37.0 & 177.0 & 77.5 & 24.7 & 3.0 \\
SD & 3.7 & 3.3 & 2.8 & 1.3 & 0.7 \\
Minimum & 35.0 & 172.0 & 73.0 & 21.8 & 2.0 \\
Maximum & 43.0 & 183.0 & 82.0 & 26.3 & 4.0 \\
\hline
\end{tabular}

Key: BMI, body mass index; $\mathrm{cm}$, centimeters; $\mathrm{kg}$, kilogram; and $\mathrm{kg} \mathrm{m}^{-2}$, kilogram per square meter. 
A pilot study was initially conducted with both machines to define the sampling in order to obtain the average values of vibration levels to define the minimum number of repetitions required at the $95 \%$ probability level, and with an admissible error limit of 5\%, as proposed by Conaw (1977) and described in equation (1).

$$
\mathrm{n}=\frac{\mathrm{t}^{2} \times \mathrm{s}^{2}}{\mathrm{E}^{2}}
$$

In which: $\mathrm{n}$ is number of samples required; $\mathrm{t}$ is $\mathrm{t}$-value, for the desired probability level and ( $\mathrm{n}-1)$ degrees of freedom; $\mathrm{s}$ is standard deviation; and, $\mathrm{E}$ is allowable error limit, in percent.

The WBV exposure levels of the operators in both machines were obtained through a Brüel and Kjaer triaxial vibration meter, model Type 4447, which provided the vibration sum of each axis in an integrated manner, and acceleration according to the criteria established by the Occupational Hygiene Standard 09 - NHO 09 (FUNDACENTRO, 2013). The accelerometer DeltaTron Seat Pad Accelerometer Type 4515-B-002 was fixed on the seat of the machines by adhesive tapes and the meter was fixed to the operators' waist.

The technical procedures of NHO 09 establish that the acceleration values should be obtained in a weighted manner in the three orthogonal axes ( $x, y$ and $z$ ) for the analysis of occupational exposure to identify the occupational exposure in a standard work day of eight hours (aren) (2). And, if higher frequencies of vibration peaks are identified, the vibration dose values (VDVR) should also be calculated (3) (FUNDACENTRO, 2013). The values from the results found were compared with the exposure limits to whole body vibration proposed by the standard, as described in Table 4.

$$
\operatorname{aren}=\operatorname{are} \times \sqrt{\frac{\mathrm{T}}{\mathrm{T}_{0}}}
$$

In which: are is acceleration resulting from exposure, representative of daily occupational exposure (m s-2); $\mathrm{T}$ is the duration of the daily work day expressed in hours or minutes; and, $\mathrm{T}_{0}$ is 8 hours or 480 minutes.

$$
\operatorname{VDVR}=\left[\sum_{\mathrm{j}}\left(\mathrm{VDV} \times \mathrm{exp}_{\mathrm{j}}\right)^{4}\right]^{1 / 4}
$$

In which: $\mathrm{VDV}_{\text {expj }}$ is vibration dose value of exposure representative of daily occupational exposure on the "j" axis, where "j" equals "x", "y" or "z" $\left(\mathrm{m} \mathrm{s}^{-1.75}\right)$.

\begin{tabular}{|c|c|c|c|}
\hline $\operatorname{aren}\left(\mathrm{m} \mathrm{s}^{-2}\right)$ & $\operatorname{VDVR}\left(\mathrm{m} \mathrm{s}^{-1.75}\right)$ & Technical Consideration & Recommended Performance \\
\hline 0 to 0.5 & 0 to 9.1 & acceptable & $\begin{array}{l}\text { At the very least maintenance of the } \\
\text { existing condition. }\end{array}$ \\
\hline$>0.5$ to $<0.9$ & $>9.1$ to $<16.4$ & above the action level & $\begin{array}{l}\text { At the very least adoption of } \\
\text { preventive measures. }\end{array}$ \\
\hline 0.9 to 1.1 & 16.4 to 21 & uncertainty region & $\begin{array}{l}\text { Adoption of preventive and } \\
\text { corrective measures aimed at } \\
\text { reducing daily exposure }\end{array}$ \\
\hline Over 1.1 & Over 21 & above the exposure limit & Immediate corrective action \\
\hline
\end{tabular}

Table 4. Exposure limits to whole-body vibration according to NHO 09.

Tabela 4. Limite de exposição à vibração do corpo inteiro Segundo a NHO 09.

Legend: aren, is normalized exposure resultant acceleration; VDVR, is Vibration Dose Resultant Value; m, is meters; and s, is seconds.

The acceleration was analyzed in different frequency ranges in order to verify in which ranges the highest vibration levels occurred. The vibration frequency range is a criterion to be analyzed in exposure to vibration due to the values that allow resonance with each region of the human body (RASMUSSEN, 1982), being able to point out some of the main symptoms caused in certain ranges of vibration frequencies and the resonance frequencies according to the regions of the human body (Table 5). 
Table 5. Symptoms related to the frequency ranges of vibration; and vibration frequencies of the human body (RASMUSSEN, 1982).

Tabela 5. Sintomas relacionados com as gamas de frequência de vibração; e frequências de vibração do corpo humano (RASMUSSEN, 1982).

\begin{tabular}{ccc}
\hline Symptoms & Frequency $(\mathrm{Hz})$ \\
\hline Generalized discomfort & $4-9$ & $13-20$ \\
Jead Symptoms & $6-8$ \\
Influence on speech & $13-20$ \\
Ciscomfort in the esophagus and throat & $12-16$ & $5-7$ \\
The urge to urinate & $4-10$ & $10-18$ \\
Increased muscle tone & $13-20$ & $\begin{array}{c}\text { Eyeball, } \\
\text { Intraocular } \\
\text { structures } \\
(20-90 \mathrm{~Hz})\end{array}$
\end{tabular}

The Shapiro-Wilk normality test was applied for the aren and VDVR data, followed by Levene's test to check for homogeneity of variances and comparison between machines by Wilcoxon's test for independent samples $(\alpha \leq 0.05)$ using the Action Stat add-in version 3.7 in Excel 2016 software.

\section{RESULTS}

The aren and VDVR results showed statistically significant differences $(\alpha \leq 0.05)$ between bulldozer and the hydraulic excavator (Table 6), indicating higher exposure levels on the bulldozer.

Table 4. Number of samples required and Wilcoxon's p-value.

Tabela 6. Número de amostras e p-valor do teste Wilcoxon.

\begin{tabular}{ccccccccc}
\hline Machine & $\sigma$ & $\mathbf{t}$ & $\mathbf{E}$ & $\mathbf{g l}$ & $\mathbf{n}$ & $\begin{array}{c}\text { Samples } \\
\text { Collected }\end{array}$ & $\begin{array}{c}\text { Aren } \\
\text { Sig. }\end{array}$ & $\begin{array}{c}\text { VDVR } \\
\text { Sig. }\end{array}$ \\
\cline { 1 - 3 } & 0.074 & 2.635 & $5 \%$ & 7 & 12 & 15 & & \\
\hline $\begin{array}{l}\text { Hydraulic } \\
\text { Excavator }\end{array}$ & 0.071 & 2.365 & $5 \%$ & 7 & 11 & 15 & & 0.0003 \\
\hline
\end{tabular}

Legend: $\sigma$, standard deviation; t, tabulated value at 95\% probability; E, allowable error; gl, degrees of freedom; n, number of samples needed; aren, acceleration resulting from normalized exposure; VDVR, resulting vibration dose value; sig, significance by Wilcoxon between-machines test $(\alpha \leq 0.05)$.

The aren averages identified in both machines were shown to be above the action level and below the exposure limit (Figure 1). Moreover, the crest factors obtained in the different orthogonal axes (x, y and z) resulted in values above 9.0 in both machines, being 13.73, 13.74 and 19.87 in the bulldozer and 9.97, 13.53 and 19.25 for the hydraulic excavator, respectively. Thus, NHO 09 indicates the need to analyze occupational exposure to vibration to consider the dose levels for evaluation (VDVR). Moreover, the dose levels also resulted in values above the action level and below the exposure limit in both machines. 

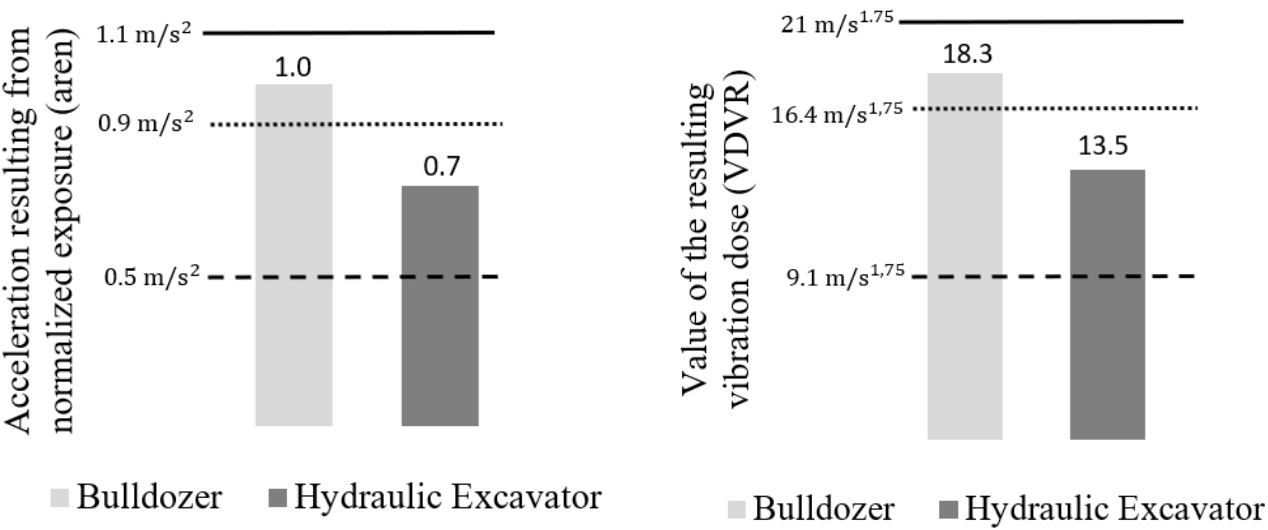

Figure 1. Aren (left); and VDVR (right) values for the evaluated machines. In which: dashed line refers to the action level, dotted line refers to the uncertainty level, and solid line refers to the exposure limit indicated in NHO 09.

Figura 1. Valores de aren (esquerda); e VDVR (direita) para as máquinas avaliadas. Em que linha tracejada se refere ao nível de ação, linha pontilhada refere-se ao nível de incerteza e linha sólida refere-se ao limite de exposição indicados na NHO 09.

Figure 2 presents the acceleration values resulting from exposure at the respective frequencies that occurred in the different orthogonal axes. The results showed that the highest vibration levels occurred in the ranges between 2 and $8 \mathrm{hz}$, indicating higher risks in this frequency range.

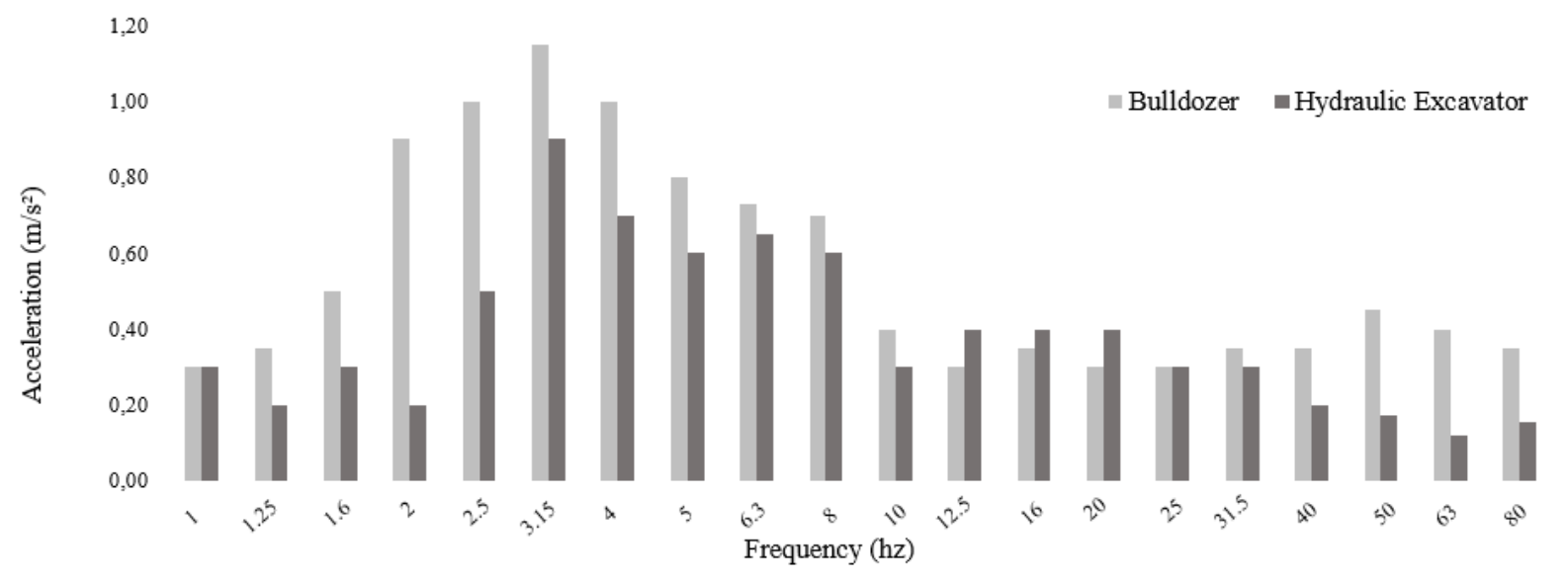

Figure 2. Whole-body vibration exposure in the frequency domain.

Figura 2. Exposição da vibração de corpo inteiro no domínio da frequência.

\section{DISCUSSION}

The bulldozer presented average VCI levels above the hydraulic excavator, with aren and VDVR values of $1.0 \mathrm{~m} \mathrm{~s}^{-2}$ and $18.3 \mathrm{~m} \mathrm{~s}^{-1.75}$ for the bulldozer, and $0.7 \mathrm{~m} \mathrm{~s}^{-2}$ and $13.5 \mathrm{~m} \mathrm{~s}^{-1.75}$ for the hydraulic excavator, respectively (Figure 1). The results found can be attributed to several influencing factors, from operational aspects related to the topography of the terrain and the presence of obstacles on the ground, to the design characteristics of the machines. However, despite the bulldozer presenting better structural conditions, the operational characteristics were determinant for the results, therefore constituting the machine with the highest vibration exposure levels for the operators.

The physical characteristics of the machines should be highlighted, because the bulldozer operated with two implements at the same time, namely a subsoiler and a "V" blade. With this, it was observed that the operational weight of the machine and the effort of the machine were high, possibly influencing the increase in vibration levels during the operation. On the other hand, the hydraulic excavator had no increase in operating weight and drag area on the ground because the implement used has the same characteristics as the original implement of the machine (a digging bucket). 
Although the machines are similar in terms of the usage time (useful life), it was found that the characteristics of the machines did not corroborate the results obtained, therefore showing that the operational characteristics were determinant for the higher occupational vibration levels in the bulldozer. During data collection, the operators reported that the hydraulic excavator had greater wear of the physical components, with the machine seat presenting cracks in the surface, and the presence of noises during operation, characteristic of wear and lack of proper lubrication of the metallic components of the external structure. This did not occur in the bulldozer, which presented better seat conditions regarding the aspect of design, material, and conservation. For Ji et al. (2017), the quality of the seat's production material is fundamental for reducing vibration levels felt by the operator. In addition, Paddan et al. (2012) mention that the angulation of the backrest can influence the vibration frequency, and may approach the natural frequency of some members of the human body, and thus bring damage to health.

It is worth mentioning that the hydraulic excavator constantly rotated $360^{\circ}$ to both sides during the operation, which may justify the noises caused by friction between the machine components. On the other hand, the bulldozer always operated in rows, and it was only necessary to turn the machine at the end of the row on the edges of the field, requiring less effort and causing less friction between the machine components. Therefore, if the characteristics of the hydraulic excavator in terms of machine design were dimensioned for the soil preparation operation or if the operation were performed in longer cycles and with less demand for machine rotation, the vibration levels would possibly be reduced.

When analyzing the operational characteristics of the machines, it was observed that the bulldozer performed the operation in constant displacement and most of the time with the implements inserted in the soil. Therefore, it is understood that the machine displacement along with the subsoiling and lowering of the stumps are the main factors which justify the high acceleration levels during the operation, being higher than the acceleration levels found in the hydraulic excavator.

On the other hand, the hydraulic excavator always performed the operation with the tracks fixed to the ground, with the machine angled at $360^{\circ}$ and inserting the subsoiling rods into the soil in four directions, following the "cross" format. This operational characteristic may justify the lower vibration levels of the machine in comparison with the bulldozer; however, the subsoiling, as well as the constant movement of the machine to both sides, may justify the high vibration levels found. Furthermore, it should be noted that the hydraulic excavator performed the operation in more extreme conditions in terms of slope (20 to $\left.30^{\circ}\right)$, thus requiring greater structural effort from the machine during the operation due to instability in the soil. Thus, the machine may suffer greater WBV incidence during the operation.

It is worth remembering that the two machines were employed in different terrain slope conditions, with the bulldozer usually being used on slopes that vary between 0 and 20 degrees and the hydraulic excavator between 20 and 30 degrees. Despite the different operational conditions between the machines, the comparison between them was necessary to verify the possibility of rotating the functions between the operators in case one of the machines presented lower WBV levels in relation to the other.

The influence of terrain characteristics on the exposure levels to whole body vibration was also reported by Rehn et al. (2005), who mention that the vibration magnitude can be reduced according to the terrain slope. Other studies have demonstrated the health risks that exposure to vibration in forestry machines can cause, either due to operational factors or physical characteristics of the machines (ALMEIDA et al., 2015; HÄGGSTRÖM et al., 2016; SCHETTINO et al., 2017; POJE et al., 2019).

It was observed that the vibration dose (VDVR) values were above the action level in both machines; however, the dose levels in the bulldozer exceeded the level of uncertainty, thus demonstrating greater occupational risk to operators in this machine. The vibration peaks are characterized by the "bumps" or jolts typical of this type of operation.

The high dose levels in the bulldozer can be justified by the impact generated by front blade contact with the stumps, generating bumps in the machine. It is also noteworthy that this condition was reported by the machine operators, indicating the frequent discomfort that this impact can cause. On the other hand, the hydraulic excavator, despite presenting lower VDVR values than the bulldozer, also obtained values above the action level. In this case, the dose values can be justified by the impacts generated from the subsoiling rods with the soil, which were inserted two or three times in each direction.

The dominant frequency range in the respective vibration levels is also an important factor to consider. Figure 2 presents the instantaneous acceleration levels as a function of the respective dominant frequency ranges in which they occurred. When analyzed in terms of frequency, it can be seen that vibration levels occurred at highest intensity in the ranges between 2 and $8 \mathrm{hz}$ on both machines. This result is an important indication of the working conditions, as the human body is more sensitive in this frequency range (RASMUSSEN, 1982). 
Several studies have shown that forestry machine operations expose operators to high vibration levels during the work shift, as well as to vibration frequencies that are harmful to health (REHN et al., 2009; JI et al., 2017; SCHETTINO et al., 2019).

The exposure levels to whole-body vibration demonstrated the need to adopt preventive measures, however, with the need for constant evaluations in order to maintain exposure levels and prevent them from exceeding the exposure limit, and in turn avoid the need for corrective measures, which require correcting the damage already caused to the worker. According to Regulatory Standard NR 9, the preventive measures should consist of a periodic evaluation of the workers to check the effects of occupational exposure to vibration, aiming at introducing or modifying control measures when necessary. In addition, the operators must be oriented as to the risks arising from and the care required to reduce exposure to vibration, since vibration levels may vary throughout the life of the machine, as well as the need for periodic and corrective maintenance.

\section{CONCLUSIONS}

- The aren and VDVR levels were higher in the bulldozer, demonstrating that the workstation of this machine can generate greater ergonomic problems for operators in terms of vibration exposure;

- The operational characteristics of the bulldozer, with the joint use of a subsoiler and a front blade, increasing the operational weight, negatively influenced the vibration levels of this machine; and,

- The operational and design characteristics of the hydraulic excavator justified the high vibration levels found in this machine, being influenced by the steep slope and constant turning of the machine during operation.

\section{ACKNOWLEDGEMENTS}

This study was carried out with support from the Conselho Nacional de Desenvolvimento Científico $e$ Tecnológico (CNPq), Klabin S/A and the Universidade Estadual do Centro-Oeste (UNICENTRO).

\section{REFERENCES}

ADAM, S. A.; JALIL, N. A. A. Vertical suspension seat transmissibility and seat values for seated person exposed to whole-body vibration in agricultural tractor preliminary study. Procedia Engineering, Selangor, v. 170 p. 435 442, 2017.

ALVARES, C. A.; STAPE, J. L.; SENTELHAS, P. C.; GONÇALVES, J. L. M.; SPAROVEK, G. Köppen's climate classification map for Brazil. Meteorologische Zeitschrift, Piracicaba, v. 22, p. 711-728, 2013.

BURSTRÖM, L.; NILSSON, T.; WAHLSTRÖM, J. Whole-body vibration and the risk of low back pain and sciatica: a systematic review and meta-analysis. International Archives of Occupational and Environmental Health, Umea, v. 88, p. 403-418, 2015.

CONAW, P. L. Estatística. São Paulo: E. Bluncher, 1977. 264 p.

FUNDACENTRO - FUNDAÇÃO JORGE DUPRAT FIGUEIREDO DE SEGURANÇA E MEDICINA DO TRABALHO. Norma de Higiene Ocupacional NHO 09 - Procedimento Técnico - Avaliação da Exposição Ocupacional a Vibração de Corpo Inteiro. São Paulo: FUNDACENTRO, 2013, 64 p.

GERASIMOV, Y.; SOKOLOV, A. Ergonomic evaluation and comparison of wood harvesting systems in Northwest Russia. Applied Ergonomics, Petrozavosdk, v.45, p. 318-338, 2014.

GONÇALVES, S. B.; LOPES, E. S.; FIEDLER, N. C.; CAVALIERI, K. M. V.; STAHL, J.; DRINKO, C. H. F. Efeito da profundidade de trabalho na qualidade da operação de subsolagem para implantação florestal. Revista Árvore, Viçosa, v. 40, n. 1, p. 29-37, 2016.

GUERRA, S. P. S.; OGURI, G.; MASCHETTI, S. H. Levantamento do nível de mecanização na silvicultura Edição 2018/2019. IPEF: Piracicaba, 2020. 61 p.

HÄGGSTRÖM, C.; ÖHMAN, M.; BURSTRÖM, L.; NORDFJELL, T.; LINDROOS, O. Vibration Exposure in Forwarder Work: Effects of Work Element and Grapple Type. Croatian Journal of Forest Engineering, Zagreb, v. 37, n. 1, p. 107-118, 2016.

INDÚSTRIA BRASILEIRA DE ÁRVORES - IBÁ. Relatório 2018. Brasília, BR: Pöyry Ltda, 2019. 79 p.

INTERNATIONAL ORGANIZATION FOR STANDARDIZATION - ISO. ISO guide for the evaluation of human exposure to whole-body vibration. ISO 2631 - 1978. ISO, Geneva, 1978. 15 p. 
JI, X.; EGER, T.R.; DICKEY, J. P. Evaluation of the vibration attenuation properties of an air-inflated cushion with two different heavy machinery seats in multi-axis vibration environments including jolts. Applied Ergonomics, Ontario, v. 59, p. 293-301, 2017.

LABELLE, E.R.; SYCHEVA, L.B.E. Exploring the use of harvesters in large-diameter hardwood-dominated stands. Forests, Freising, v. 9, f9070424, 2018.

MALINEN, J.; TASKINEN, J.; TOLPPA, T. Productivity of cut-to-legth harvesting by operators age and experience. Croatian Journal of Forest Engineering, Zagreb. v. 39, p. 15-22, 2018.

PADDAN, G. S.; MANSFIELDB, N. J.; ARROWSMITHC, C.I.; RIMELLB, A.N.; KINGC, S.K. HOLMESC, S.R. The influence of seat backrest angle on perceived discomfort during exposure to vertical whole-body vibration. Ergonomics, Gosport, v. 55, n.8, p. 923-936, 2012.

POJE, A.; GRIGOLATO, S.; POTOCNIK, I. Operator exposure to noise and whole-body vibration in a fully mechanized CTL forest harvesting system in karst terrain. Croatian Journal of Forest Engineering, Zagreb, v. 40, p. 139-150, 2019.

RASMUSSEN, G. Human body vibration exposure and its measurement. Dinamarca: Bruel \& Kjaer, 1982. 39 p. (Relatório técnico, n. 1).

RAPER, R. L.; BERGTOLD, J. S. In-row subsoiling: a review and suggestions for reducing cost of this conservation tillage operation. Applied Engineering in Agriculture, Saint Joseph, v. 23, n.4, p. 463-471, 2007.

REHN, B.; LUNDSTROM, R.; NILSSON, L.; LILJELIND, I.; JARVHOLM, B. Variation in exposure to wholebody vibration for operators of forwarder vehicles - aspects on measurement strategies and prevention. International Journal of Industrial Ergonomics, Umea, v. 35, n. 9, p. 831-842, 2005.

REHN, B.; NILSSON, T.; LUNDSTRÖM, R.; HAGBERG, M.; BURSTRÖM, L. Neck pain combined with arm pain among professional drivers of forest machines and the association with whole-body vibration exposure. Journal Ergonomics, Umea, v. 52, n. 10, p. 1240-1247, 2009.

RODRIGUES, C.K.; LOPES, E.S.; POLIZELI, K.M.V.C.; MÜLLER, M.M.L. Compactação do solo devido ao tráfego de colheita de madeira em diferentes distâncias de extração. Floresta e Ambiente, Seropédica, v. 25, n.2, p.e20160045, 2018.

SALIBA, T. M. Manual Prático de Avaliação e Controle de Vibração - PPRA. São Paulo: LTr. 2019. 112 p.

SANTOS, H. G.; JACOMINE, P. K. T.; ANJOS, L. H. C.; OLIVEIRA, V. A.; LUMBRERAS, J. F.; COELHO, M. R.; ALMEIDA, J. A.; ARAUJO FILHO, J. C.; OLIVEIRA, J. B.; CUNHA, T. J. F. Sistema Brasileiro de Classificação de Solos. 5. ed., Brasília, DF: Embrapa, 2018. 353 p.

SCHETTINO, S., MINETTE, L.J., CAÇADOR, S.S., REBOLETO, I.D. Assessment of Occupational Vibration on Tire $\times$ Track Harvesters in Forest Harvesting. Proceedings of the 20th Congress of the International Ergonomics Association (IEA 2018), Springer International Publishing, Viçosa p. 31- 40, 2019.

SCHETTINO, S.; CAMPOS, J. C. C.; MINETTE, L. J.; SOUZA, A. P. Work precariousness: Ergonomic risks to operators of machines adapted for forest harvesting. Revista Árvore, Viçosa, v. 41, n.1, e410109, 2017. 